\title{
Morel berry leaf extract reduce levels of reactive oxygen species and increase levels of endothelial nitric oxide synthase of male Wistar rat exposed to cigarette smoke
}

Felicia Hartono',

Gde Ngurah Indraguna Pinatih', Anak Agung Ayu Ngurah Susraini ${ }^{1}$

Master Program in Biomedical Science, Concentration in Anti-Aging Medicine, Medical Faculty Udayana University, Bali, Indonesia

\section{Cite this article:}

Hartono F, Pinatih GNI \& Susraini AAAN. Morel berry leaf extract reduce levels of reactive oxygen species and increase levels of endothelial nitric oxide synthase of male Wistar rat exposed to cigarette smoke. Neurologico Spinale Medico Chirurgico. 202I.4(I):28-3I. DOI:

I0.36444/nsmc.v4il.| 48

\section{Corresponding author:}

Felicia Hartono

Master Program in Biomedical Science, Concentration in Anti-Aging Medicine, Medical Faculty Udayana University, Bali, Indonesia.

felicia_hartono@hotmail.com

\begin{abstract}
Background: Exposure to cigarette smoke increased the level of reactive oxygen species (ROS) and caused oxidative stress which could lead to early aging includes vascular aging Morel berry leaf contained flavonoid works as antioxidant that neutralized ROS. This study aimed to investigate effectivenes of Morel berry (Physalis angulata L.) leaf extract to decrease levels of ROS and increase levels of endothelial nitric oxide synthase (eNOS) in male Wistar rats exposed to cigarette smoke.
\end{abstract}

Methods: This research was an experimental study with pre test-post test control group design. 16 healthy male rats (Rattus norvegicus), Wistar strain, 3-4 months, weight 180-200gr were used, divided randomly into two groups. The control group was given aquadest and the treatment group was given Morel berry leaf extract $500 \mathrm{mg} / \mathrm{kgBW} / \mathrm{day}$. Continued to 30 minutes exposed to cigarette smoke. ROS and eNOS levels were measured before and after 28 days treatment, using rat ROS ELISA Kit and rat ENOS ELISA Kit respectively.

Results: The results showed that the mean ROS levels in the treatment group decreased significantly and was significantly lower than in control group $(75.789 \pm 3.298$ vs $91.646 \pm$ 1.970; $\mathrm{p}<0.001)$. The mean eNOS levels in the treatment group increased significantly and was significantly higher than control group $(8.597 \pm 0.375$ vs $5.957 \pm 0.329 ; \mathrm{p}<0.001)$.

Conclusion: The results of this study indicated that administration of Morel berry leaf extract reduced levels of ROS and increased serum levels of eNOS in male Wistar rats exposed to cigarette smoke.

Keywords: Morel berry leaf extract, ROS levels, eNOS levels, Cigarette smoke

\section{Introduction}

Cigarette smoke contains more than 4,800 chemical materials, including tar, nikotin, carbon monoxide and nitric oxide. ${ }^{1}$ Constituents of cigarette smoke have been shown to induce and activate reactive oxygen species (ROS)-producing enzyme systems within the vascular wall thereby increasing ROS production, leading to decrease endogenous antioxidants and result to oxidative stress that could lead to endothelial dysfunction and it is a part of vascular aging 
process. $^{2}$

Endothelial nitric oxide synthase (eNOS) is an enzyme that plays a role in the formation of nitric oxide (NO) in the endothelium of blood vessels. ${ }^{3}$ Imbalance of decreasing NO production and increasing ROS production, especially superoxide, can cause endothelial dysfunction. Decreasing of eNOS level can reduce the biovailability of nitric oxide and cause endothelial dysfunction, which is an initiation for atherosclerosis and other vascular diseases. ${ }^{4}$ It is hoped that by enhancing eNOS expression will prevent the development of atherosclerosis, thereby reducing the number of cardiovascular and cerebrovascular events. $^{3}$

ROS can be neutralized by antioxidant. Morel berry (Physalis angulata L.) is easily found in Indonesia. The antioxidant contents of Morel berry leaves are flavonoid (quercetin, quercetin 3-O-methyl ether, isoquercetrin and Kaempferol 7-O-rhamnoside), polyphenols and tannin. ${ }^{5}$ Flavonoids could act as antioxidants through direct scavenging mechanisms and prevented oxidation of nicotinamide adenine dinucleotide phosphate (NADPH). ${ }^{6}$ Quercetin induced phosphorylation of eNOS at serine 1179 and activated eNOS. ${ }^{7}$ Antioxidant can prevent the oxidative damage and this study tried to clarify the effectiveness of Morel berry leaves extract in preventing vascular aging caused by cigarette smoke exposure.

\section{Methods}

This research has been approved by the Ethics Committee of the Faculty of Veterinary Medicine of Udayana University on November 25, 2019 under number 1734 / UN14.2.2.VII.14 / LT / 2020. This research used a randomized pretest-posttest control group design.

The procedure for making extracts of Morel berry leaf was as follows: $3 \mathrm{~kg}$ Morel berry leaves taken from plantations in the Jember area were dried by aerating for 7-days, then grounded using a disc mill to obtain a powder form. Then the powder was macerated in a $96 \%$ solvent (ethanol) for 48-hours to attract the active substance. The filtrate was obtained by filtering through 4 layers of gauze followed by filtering using Whatman filter paper no. 1. The filtrate obtained was then evaporated using a vacuum rotary evaporator at $40^{\circ} \mathrm{C}$, so an extract of 26 grams was obtained. The results from phytochemical test showed that morel berry leaf contained flavonoid 1,804.68 mg/100mg, phenol 3,589.83 mg/100mg gallic acid equivalent (GAE), tannin 3,010.83 mg/100mg tannic acid equivalent (TAE), IC50 $168.45 \mathrm{mg} / \mathrm{L}$ and antioxidant capacity 1,431.02 mg/L gallic acid equivalent antioxidant capacity (GAEAC).

The subjects were 16 male rats (Rattus norvegicus) Wistar strain, healthy, 3-4 months old, and weight 180-200 grams. All rats were adapted for 7-days before treatment and then divided randomly into 2 groups. The control group was given the aquadest and then exposed to cigarette smoke and the treatment group was given $500 \mathrm{mg} / \mathrm{kg}$ body weight/day Morel berry leaf extract and exposed them with cigarette smoke for 30-minutes. ROS and eNOS levels was measured by examining blood serum before and after 28-days treatment using ELISA method. ${ }^{8,9}$

ROS was measured with the Rat Reactive Oxygen Species ELISA Kit and eNOS was measured with the Rat Endothelial Nitric Oxide Synthase (eNOS/NOS3) ELISA Kit. The procedure using standard procedure written for ELISA Kit. ${ }^{9,10}$

All data collected was tested for data normality with ShapiroWilk and homogeneity test using Levene's test. Furthermore, descriptive analysis and comparative analysis will be carried out using parametrical statistic tests with independent sample t-test (between group) and paired t-test (inter group).

\section{Results}

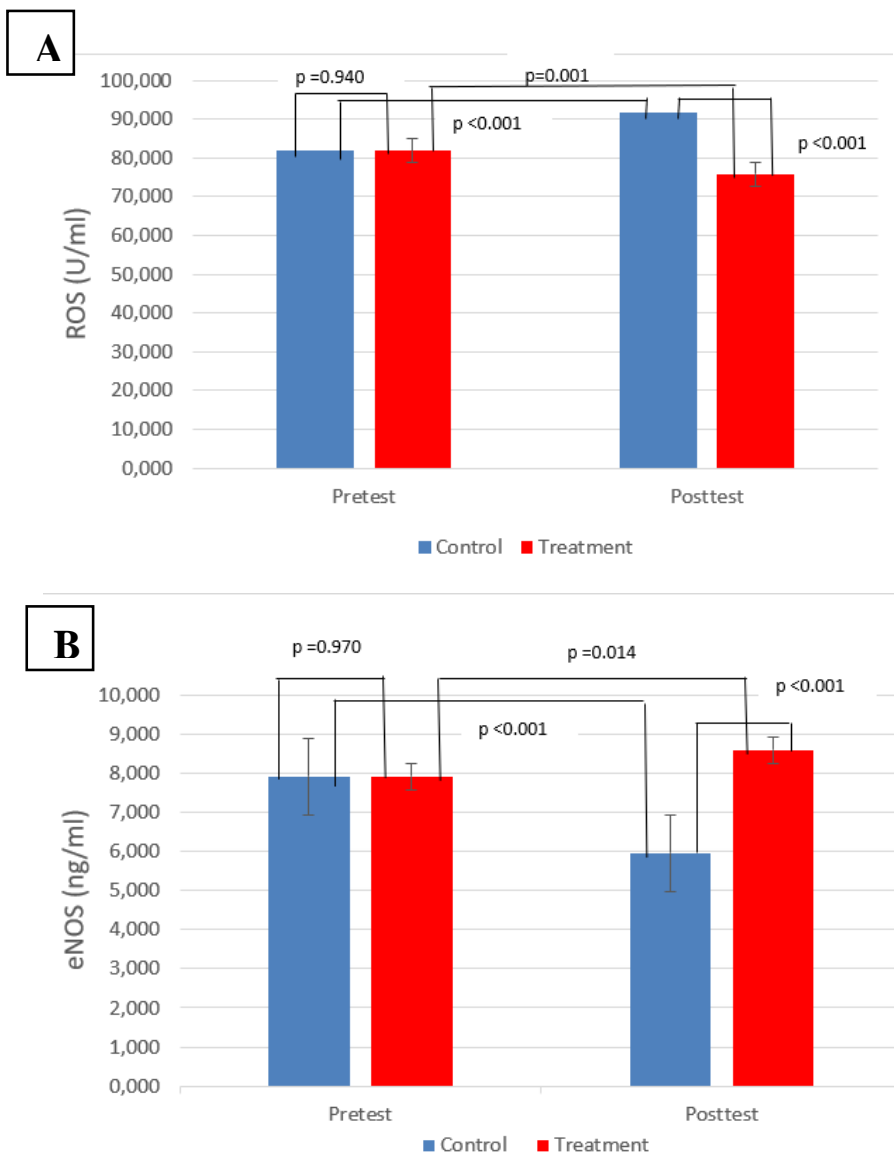

Figure 1. (A) Comparison of ROS levels and (B) comparison of eNOS levels between groups 
The results (Figure 1) showed that before the treatment, the average of ROS level in both the control group and treatment group were insignificantly different $(81.92 \pm 1.66 \mathrm{U} / \mathrm{ml}$ and $81.86 \pm 1.64 \mathrm{U} / \mathrm{ml}$ respectively, $\mathrm{p}=0.940$ ). Similar to the average eNOS level before the treatment, in the control group was $7.92 \pm 0.42 \mathrm{ng} / \mathrm{ml}$ and the treatment group was $7.91 \pm 0.45 \mathrm{ng} / \mathrm{ml}(\mathrm{p}=0.970)$ which means that they were insignificantly different.

After being treated for 28 days, the average ROS level in both groups has significantly changed. The ROS level in the control group increased significantly ( $\mathrm{p}<0.001$ ) became $91.65 \pm 1.97 \mathrm{U} / \mathrm{ml}$ and the treatment group decreased significantly $(\mathrm{p}=0.001)$ became $75.79 \pm$ $3.30 \mathrm{U} / \mathrm{ml}$. The average eNOS level in both groups also has significantly changed. The average eNOS level in the control group was decreased significantly ( $\mathrm{p}<0.001$ ) became $5.96 \pm 0.33 \mathrm{ng} / \mathrm{ml}$ and the treatment group was increased significantly $8.60 \pm 0.38 \mathrm{ng} / \mathrm{ml}(\mathrm{p}=$ 0.014). They both ROS and eNOS between control and treatment group became significantly different ( $\mathrm{p}<0.001$ and $\mathrm{p}<0.001$ respectively).

\section{Discussion}

Cigarette smoke produces free radicals. The oxidized chemical materials in cigarette smoke had been induced and activated ROSproducing enzyme systems within the vascular wall thereby increasing ROS production, leading to decrease endogenous antioxidants and result to oxidative stress that could lead to endothelial dysfunction. ${ }^{2}$

This research supported the study done by Surya (2020) that cigarette smoke can significantly increase malondialdehyde (MDA) production and decrease eNOS degeneration. MDA is one of the final products of lipid peroxidation and commonly known as marker of oxidative stress. ${ }^{9}$ From the result of comparability test, within the posttest, the treatment group had a lower ROS level and higher eNOS level compare to the control group. It meant that ethanol extract from morel berry leaves prevented even decreased ROS production and eNOS degeneration in rats after being exposed to cigarette smoke. So that, we could conclude that ethanol morel berry extract could prevent endothelial dysfuction which is part of vascular aging process. This finding supported the study carried out by Debiasista that morel berry leaves extract prevented a decrease in superoxide dismutase (SOD) levels and an increase in MDA serum in male Wistar rats (Rattus norvegicus) exposed to cigarette smoke. SOD is an endogenous antioxidant that alternately catalyzes the dismutation of superoxide radicals into molecular oxygen and hydrogen peroxide. So free radicals that are suppressed by antioxidants from morel berry leaves reduce oxidative stress, which is indicated by not increasing MDA levels. ${ }^{8}$ The result from this study also prove that morel berry leaf could neutralize ROS and prevent oxidative stress.

Morel berry leaves contains flavonoid (quercetin, quercetin 3O-methyl ether, isoquercetrin and Kaempferol 7-O-rhamnoside), polyphenols and tannin. ${ }^{5}$ Quercetin increases intracellular calsium concentration rapidly and stimulates eNOS phosphorylation which has an effect on increasing NO production. Quercetin mediated stimulation of eNOS phosphorylation and then increases NO availability in endothelial cells and thus may play a role in the vascular protective effect associated with increased endothelial cell function. ${ }^{7}$ Flavonoid could act as potential antioxidant through direct free radical scavenger mechanism. Flavonoid will give its hydrogen atom on radical oxygen and prevent peroxynitrite production. ${ }^{11}$ Besides being direct antioxidants, Flavonoid also has a function as a NADPH oxidase inhibitor. ${ }^{6}$ This inhibition will increase the NO production and prevent eNOS uncoupling. ${ }^{12}$

Result of this study is along with research from Febianti et al., (2019) which stated that the administration of Physalis angulata $L$ extract has a vasoprotective effect by preventing kidney vascular rarefaction, oxidative stress and inflammation on L-NAME-induced male Wistar rat. At the dose of $500 \mathrm{mg} / \mathrm{kg} /$ day and $1,500 \mathrm{mg} / \mathrm{kg} /$ day, $P$. angulata leaf water extract supplementation increased the vascular density, decreased the MDA level, and decreased the NF- $\kappa B$ expression compared to the L-NAME group. ${ }^{13}$

\section{Conclusion}

In conclusion, the result of this study indicated that administration of the ethanol extract from morel berry (Physalis angulata L.) leaves reduced levels of reactive oxygen species (ROS) and increased levels of endothelial nitric oxide synthase (eNOS) in male Wistar rats after being exposed to cigarette smoke. Further research is needed to see side effect of giving morel berry leaves over a longer period of time.

\section{Acknowledgment}

None.

\section{References}

1. Tirtosastro S, Murdiyati AS. Kandungan kimia tembakau dan rokok. Buletin Tanaman Tembakau, Serat dan Minyak Industri. 2017;2(1):3344. DOI: 10.21082/bultas.v2n1.2010.33-44 
2. Messner B, Bernhard D. Smoking and cardiovascular disease: Mechanism of endothelial dysfunction and early atherogenesis. Arterioscler Thromb Vasc Biol. 2014;34(3):509-515. DOI: 10.1161/ATVBAHA.113.300156

3. Forte A, Conti V, Damanto A, et al. Targeting nitric oxide with natural derived compounds as a therapeutic strategy in vascular diseases. Oxidative Medicine and Cellular Longevity. 2016;2016:7364138. DOI: $10.1155 / 2016 / 7364138$

4. Higashi Y, Kihara Y, Noma K. Endothelial dysfunction and hypertension in aging. Hypertension Research. 2012;35(11):10391047. DOI: $10.1038 / \mathrm{hr} .2012 .138$

5. Augustine AA, Ufuoma O. Flavonoids from the leaves Physalis angulata Linn. Planta Med. 2013;79:PJ5. DOI: 10.1055/s-00331352209

6. Zeka K, Ruparelia K, Arroo R, et al. Flavonoids and their metabolites: Prevention in cardiovascular diseases and diabetes. Diseases. 2017;5(3):19. DOI: $10.3390 /$ diseases5030019

7. Khoo NKH, White CR, Pozzomiller L, et al. Dietary flavonoid quercetin stimulates vasorelaxation in aortic vessels. Free Radical Biology and Medicine. 2010;49(3):339-447. DOI: 10.1016/j.freeradbiomed.2010.04.022

8. Debiasista IM. Pemberian ekstrak daun ciplukan (Physalis angulata L.) menghambat penurunan superoxide dismutase (SOD) dan peningkatan malondialdehyde (MDA) serum pada tikus (Rattus norvegicus) Wistar jantan yang diberi paparan asap rokok [Thesis]. Denpasar: Fakultas Kedokteran Universitas Udayana. 2019.
9. Surya BR. Pemberian ekstrak etanol buah buni (Antidesma bunius L.) menurunkan kadar Malonialdehyde (MDA) dan mempertahankan kadar endothelial nitric oxide synthase (eNOS) serum tikus (Rattus norvegicus) galur Wistar jantan yang dipapar asap rokok [Thesis]. Denpasar: Fakultas Kedokteran Universitas Udayana. 2020.

10. Huang T, Zhou F, Yuan X, et al. Reactive oxygen species are involved in the development of gastric cancer and gastric cancer-related depression through ABL-1 mediated inflammation signaling pathway. Oxidative Medicine and Cellular Longevity. 2019;2019:5813985. DOI: $10.1155 / 2019 / 5813985$

11. Akhlaghi M, Brian B. Mechanism of flavonoid protection against myocardial ischemia reperfusion injury. Journal of Molecular and Cellular Cardiology. 2009;46(3):309-317. DOI: 10.1016/j.yjmcc.2008.12.003

12. Förstermann U, Li H. Therapeutic effect of enhancing endothelial nitric oxide synthase (eNOS) expression and preventing eNOS uncoupling. British Journal of Pharmacology. 2011;164:213-223. DOI: 10.1111/j.1476-5381.2010.01196.x

13. Febianti Z, Permatasari N, Soeharto S. Vasoprotective effect of Physalis angulata L. leaf water extract on kidney of ni(C-nitro-l-arginine methyl ester-induced endothelial dysfunction rat model. Asian Journal of Pharmaceutical and Clinical Research. 2019;12(1):432. DOI: 10.22159/ajpcr.2019.v12i1.29857 